\title{
Analisis Tingkat Kebangkrutan Pada Perusahaan Asuransi Yang Terdaftar Di Bursa Efek Indonesia
}

\author{
Mikha Novalina Sinaga \\ Frendy A.O.Pelleng \\ Joan V. Mangindaan \\ Jurusan Ilmu Administrasi Program Studi Administrasi Bisnis \\ Fakultas Ilmu Sosial dan Ilmu Politik Universitas Sam Ratulangi Manado \\ Email:mikhanovalina@gmail.com
}

\begin{abstract}
The purpose of this research study is to determine the result of prediction analysis of potential bankruptcy on eleven insurance companies sector which has been listed in Indonesia Stock Exchange year 2015 to 2018. Bankruptcy is a condition when a company experiences insufficient funds to run its business. Bankruptcy is uncertainty about the ability of a company to continue its operations if the financial condition held has decreased. In fact, not all companies experience financial management problems that often lead to bankruptcy. Based on the result and conclusions of the analysis using Altman Z-Score method that: in 2015-2018 there were several companies that were safe, namely: PT. Bina Dana Arta Insurance Tbk, PT. Harta Aman Pratama Insurance Tbk, PT. Jasa Tania Insurance Tbk, PT Indonesian reinsurance airline Tbk, PT. Panin Insurance Tbk, PT. Panin Financial Tbk, PT Victoria Insurance Tbk. Then there are companies that in 2015- 2017 are healthy but in 2018 in prone conditions, namely: PT. Bintang Insurance Tbk, and PT. Multi Artha Guna Insurance Tbk, but different from PT. Mitra Maparya Insurance Tbk which in 2015 was in vulnerable condition but in 2016-2018 is safe. And PT. Ramayana from 2015-2018 is in vulnerable condition.
\end{abstract}

Keywords : Insurance Companies, Bankruptcy, Altman Z-Score

\section{Pendahuluan}

Secara umum setiap perusahaan pasti mempunyai tujuan untuk menghasilkan laba yang sebesar-besarnya untuk kepentingan perusahaan itu sendiri. Perusahaan merupakan suatu badan yang didirikan oleh perorangan atau lembaga dengan tujuan utama untuk memaksimalkan kekayaan pemegang saham. Disamping itu ada pula tujuan lain yang tidak kalah penting yaitu dapat terus bertahan (survive) dalam persaingan, semakin meningkat (grow) serta dapat melaksanakan fungsi-fungsi sosial lainnya di masyarakat. Kebangkrutan adalah suatu kondisi di saat perusahaan mengalami ketidakcukupan dana untuk menjalankan usahanya. Secara empiris prediksi kebangkrutan atau likuidasi ini dapat dibuktikan, sebagaimana yang telah dilakukan oleh beberapa peneliti dengan menggunakan rasio-rasio keuangan. 
Perusahaan perlu melakukan analisis kinerja terutama analisis yang berhubungan dengan kebangkrutan untuk mendeteksi factor- factor kebangkrutan sejak awal. Keuntungan yang didapat perusahaan apabila mengetahui factor-faktor kebangkrutan adalah dapat melakukan antisipasi yang bertujuan menghindari dan atau meminimalisir resiko kebangkrutan tersebut. Kebangkrutan tidak akan datang tiba-tiba melainkan melalui tanda-tandanya. Risiko kebangkrutan bagi perusahaan sebenarnya dapat dilihat dan diukur melalui laporan keuangan perusahaan, dengan cara melakukan analisis terhadap laporan keuangan merupakan yang dikeluarkan oleh perusahaan yang bersangkutan. Laporan keuangan merupakan salah satu sumber informasi mengenai posisi keuangan perusahaan, kinerja serta perubahan posisi keuangan yang sangat berguna untuk mendukung pengambilan keputusan yang tepat.

$$
\text { Terjadinya likuidasi atau }
$$

kebangkrutan pada sejumlah perusahaan tentu saja akan menimbulkan beberapa permasalahan yang berkaitan dengan pemilik maupun karyawan yang harus kehilangan pekerjaannya. Hal ini sebenarnya tidak akan menimbulkan masalah yang lebih besar kalau proses kebangkrutan pada sebuah perusahaan dapat diprediksi lebih dini. Adanya tindakan untuk memprediksi terjadi kebangkrutan tersebut, tentu saja akan dapat menghindari atau mengurangi risiko terjadi kebangkrutan tersebut.

Metode yang dapat digunakan untuk mendeteksi tingkat kebangkrutan dan tanda-tanda kebangkrutan suatu perusahaan adalah metode Altman (Z-score). Metode Altman (Z-score) merupakan metode prediksi kebangkrutan yang mengacu pada rasio-rasio keuangan perusahaan. Metode ini pertama diperkenalkan oleh Altman (1968) dengan menyusun suatu model yang bertujuan untuk memprediksi kebangkrutan perusahaan dan dikenal dengan istilah Altman's Bankruptcy Prediction Model (Zscore). Dalam analisis tingkat kesehatan perusahaan untuk memprediksi potensi kebangkrutan dengan pendekatan Altman. Sektor Asuransi cukup menarik dijadikan objek penelitian karena banyaknya perusahaan-perusahaan

Asuransi membanjiri pasar Indonesia. Perusahaan asuransi dalam persaingannya lebih berfokus pada kepercayaan konsumen dan memberikan produk pelayanan sesuai dengan keinginan dari konsumen. Dengan begitu, perusahaan asuransi yang ingin bersaing harus meningkatkan produk pelayanan dan kepercayaan konsumen. Jika perusahaan-perusahaan asuransi tidak bisa memenuhi keinginan konsumen maka perusahaan-perusahaan asuransi tidak akan 
berjalan dengan baik bahkan perusahaanperusahaan asuransi akan mempunyai risiko kebangkrutan yang tinggi.

Mengadakan interpretasi atau analisa terhadap laporan finansial suatu perusahaan - perusahaan asuransi akan sangat bermanfaat bagi penganalisis untuk dapat mengetahui keadaan dan perkembangan finansial dari perusahaan tersebut. Berdasarkan keadaan yang terdapat di perusahaan, maka timbul permasalahan Seberapa Besar Potensi Tingkat Kebangkrutan Pada Perusahaan Asuransi yang Terdaftar di BEI?

Tujuan penelitian artikel ini adalah untuk mengetahui seberapa besar potensi tingkat Kebangkrutan pada Perusahaan Asuransi di BEI (Bursa Efek Indonesia). Artikel ini diharapkan dapat bermanfaat secara teoritis maupun praktis untuk menambah wawasan dan pengetahuan teori kebangkrutan dan mengetahui formula Almtan Z-Score serta penerapannya bagi suatu perusahaan. Bagi perusahaan, artikel ini diharapkan dapat digunakan sebagai bahan pertimbangan untuk pengambilan keputusan dalam hal peningkatan kinerja keuangan.

\section{Kebangkrutan}

Kebangkrutan adalah suatu kondisi di saat perusahaan mengalami ketidakcukupan dana untuk menjalankan usahanya.
Kebangkrutan (bankruptcy) merupakan kondisi dimana perusahaan tidak mampu lagi untuk melunasi kewajibannya. Kondisi ini biasanya tidak muncul begitu saja di perusahaan, ada indikasi awal dari perusahaan tersebut yang biasanya dapat dikenali lebih dini kalau laporan keuangan dianalisis secara lebih cermat dengan suatu tertentu. Rasio keuangan dapat digunakan sebagai indikasi adanya kebangkrutan di perusahaan (Toto, 2011:332).

Menurut Brigham dan Houston (2012:2-3) adalah :

Kegagalan ekonomi, merupakan kondisi perusahaan dimana perusahaan mengalami kehilangan uang atau perusahaan dimana perusahaan tidak mampu menutupi biaya yang dikeluarkannya. Kegagalan keuangan merupakan kondisi perusahaan yang dimana mengalami kesulitan keuangan dana baik dalam arti dana di dalam pengertian kas ataupun dalam artian modal kerja. Dampak yang akan dihadapi ketika mengalami kebangkrutan adalah berhentinya aktivitas yang dilakukan oleh perusahaan sehingga perusahaan tidak memperoleh keuntungan bisnis. Kebangkrutan juga memberikan dampak pada kerugian yang diterima perusahaan karena mengalami gagal bayar ataupun biaya untuk tuntutan dari pihak - pihak 
yang masih menerima hak -hak atas perusahaan.

\section{Asuransi}

Menurut Subekti (2001), pengertian asuransi adalah suatu perjanjian yang termasuk dalam jenis perjanjian untunguntungan dimana perjanjian ini dengan sengaja didasarkan atas kejadian yang belum tentu terjadi di kemudian hari, kejadian mana yang akan menentukan untung ruginya salah satu pihak. Menurut Emmy Pangaribuan (1992), pengertian asuransi adalah suatu perjanjian dimana penanggung dengan menikmati suatu premi mengikatkan dirinya terhadap tertanggung untuk membebaskan diri dari kerugian karena kehilangan, kerugian atau ketiadaan keuntungan yang diharapkan yang akan dapat diderita olehnya karena suatu kejadian yang belum pasti.

\section{Analisis Altman Z-Score}

Berbagai penelitian telah dilakukan untuk mengkaji manfaat yang bisa dari analisis rasio keuangan. Edward I Altman di New York University adalah salah satu peneliti awal yang mengkaji pemanfaatan analisis rasio keuangan sebagai alat untuk memprediksi kebangkrutan perusahaan.

Altman melakukan penelitian lagi mengenai potensi kebangkrutan perusahaan-perusahaan selain perusahaan manufaktur, baik yang go public maupun yang tidak. Rumus Z-Score terakhir merupakan rumus yang sangat fleksibel karena bisa digunakan untuk berbagai jenis bidang usaha perusahaan, baik yang go public maupun yang tidak, dan cocok digunakan di Negara berkembang seperti Indonesia (Rudianto, 2013 : 257). Hasil penelitian tersebut menghasilkan rumus ZScore ketiga untuk berbagai jenis perusahaan, sebagai berikut :

Dimana :

- $X_{1}$ adalah rasio yang mengukur likuiditas dengan membandingkan asset likuid bersih dengan total asset.

- $X_{2}$ adalah rasio yang mengukur akumulasi laba selama perusahaan beroperasi.

- $X_{3}$ adalah rasio yang menjelaskan pentingnya pencapaian laba perusahaan terutama dalam rangka memenuhi kewajiban bunga para investor.

- $X_{4}$ adalah rasio yang kebalikan dari utang per modal sendiri (Debt to Equity Ratio). Nilai modal sendiri yang dimaksud adalah nilai pasar modal sendiri, yaitu jumlah saham perusahaan yang dikalikan dengan harga saham per lembarnya. Umumnya, perusahaan perusahaan yang gagal akan mengakumulasikan lebih banyak utang dibandingkan modal sendiri. 
Hasil perhitungan dengan menggunakan rumus Z-Score tersebut akan menghasilkan skor yang berbeda Antara suatu perusahaan dengan perusahaan lainnya. Skor tersebut harus dibandingkan dengan standar penilaian berikut ini untuk menilai keberlangsungan hidup perusahaan

a) Jika nilai $Z>2,60=$ Zona Aman

b) Jika nilai $1,10<\mathrm{Z}<2,60=$ Zona Abuabu/Rawan

c) Jika nilai $\mathrm{Z}<1,10=$ Zona Berbahaya

Tiga penelitian yang dilakukan Altman dengan 3(tiga) objek yang berbeda menghasilkan tiga rumus pendeteksi kebangkrutan yang berbeda. Ketiga rumus tersebut juga menggunakan standar penilaian yang berbeda. Ini dengan metode Altman Z-Score yang sudah di modifikasi dengan mengetahui nilai Z-Score suatu perusahaan, dapat diketahui kondisi badan usaha tersebut apakah mengalami masalah serius, atau menghadapi bahaya, atau masih dalam kondisi aman. Dengan analisis ZScore ini juga manajemen dapat meramalkan prospek perusahaan di masa yang akan datang dalam menjaga kelangsungan hidupnya. Semakin besar nilai “Z”, semakin besar pula jaminan akan kelangsungan hidup perusahaan dan semakin berkurang risiko kegagalan.

\section{Metode Penelitian}

Jenis Penelitian ini adalah metode penelitian deskriptif dengan menggunakan pendekatan kuantitatif. Penelitian deskriptif tidak dimaksudkan untuk menguji hipotesis tertentu, tetapi hanya menggambarkan apa adanya tentang sesuatu variable. Dalam penelitian, teknik pengumpulan data merupakan factor penting demi keberhasilan penelitian. Hal ini berkaitan dengan bagaimana cara mengumpulkan data, siapa sumbernya, dan apa alat yang digunakan.

Metode pengumpulan data yang digunakan dalam penelitian ini adalah studi perpustakaan, yaitu berupa file-file yang relevan dan sesuai dengan analisis yang diangkat yang diperoleh dari berbagai sumber. File-file tersebut berupa buku, artikel, dan laporan, dsb. Sumber data yang digunakan dalam penelitian ini adalah data sekunder, yaitu data yang diperoleh secara tidak langsung dengan mempelajari literature atau dokumen yang berhubungan dengan penelitian. Data diambil dalam bentuk yang sudah dipublikasikan oleh perusahan - perusahaan Asuransi go public di Bursa Efek Indonesia. Data tersebut Antara lain berupa gambaran umum perusahaan atau profil perusahaan, laporan keuangan perusahaan selama tahun 2015 2018. Data - data dalam penelitian ini merupakan data - data yang bersumber dari 
catatan - catatan yang dipublikasikan di Bursa Efek Indonesia dan data yang diperoleh dari www.duniainvestasi.com

\section{Hasil Penelitian}

Jadi dari hasil analisis tingkat kebangkrutan pada perusahaan asuransi yang terdaftar di BEI, yang peneliti lakukan terdapat sebelas perusahaan asuransi di antaranya terdapat tujuh perusahaan dalam kondisi aman (tidak bangkrut) dan empat perusahaan asuransi lainnya berada dalam kondisi rawan (grey area). Tujuh perusahaan yang berada dalam kondisi aman dilihat dari laporan keuangannya yang setiap tahun berjalan dengan baik seperti current ratio yang lebih besar daripada current liability. Dan berbeda dengan empat perusahaan lainnya yang setiap tahun memiliki masalah dalam manajemen laporan keuangan seperti current liability lebih besar daripada current asset, sehingga perusahaan memiliki hutang yang lebih besar daripada keuntungan. Namun keempat perusahaan ini belum tentu dinyatakan bangkrut karena perusahaan masih dalam kondisi rawan (grey area) yang dimana perusahaan sudah berupaya meningkatkan current assetnya dalam setiap tahunnya. Hasil perhitungan dan analisis metode Altman Z-Score pada perusahaan asuransi yang terdaftar di Bursa
Efek Indonesia tahun 2015 sampai dengan 2018.

\section{Analisis}

Table 1. Hasil Perhitungan dan Analisis Metode Altman Z-Score pada tahun 2015

\begin{tabular}{cc}
\hline Nama Perusahaan & Z-Score \\
\hline PT ABDA & 6,72 \\
PT AHAP & 4,32 \\
PT AMAG & 3,64 \\
PT ASBI & 3,23 \\
PT ASJT & 3,33 \\
PT ASMI & 1,55 \\
PT ASRM & 1,96 \\
PT MREI & 3,20 \\
PT PNIN & 6,44 \\
PT PNLF & 6,88 \\
PT VINS & 8,08 \\
\hline Sumber : Data yang diolah &
\end{tabular}

Tabel 2. Hasil Perhitungan dan Analisis Metode Altman Z-Score pada tahun 2016

\begin{tabular}{cc}
\hline Nama Perusahaan & Z-Score \\
\hline PT ABDA & 6,83 \\
PT AHAP & 4,04 \\
PT AMAG & 3,04 \\
PT ASBI & 3,33 \\
PT ASJT & 3,51 \\
PT ASMI & 3,34 \\
PT ASRM & 2,09 \\
PT MREI & 3,34 \\
PT PNIN & 8,11 \\
PT PNLF & 7,25 \\
PT VINS & 6,44 \\
\hline
\end{tabular}

Sumber : Data yang diolah 
Berdasarkan tabel I, II, III, dan IV

Tabel 3. Hasil Perhitungan dan Analisis Metode Altman Z-Score pada tahun 2017

\begin{tabular}{lc}
\hline \multicolumn{1}{c}{ Nama Perusahaan } & Z-Score \\
\hline PT ABDA & 6,88 \\
PT AHAP & 5,22 \\
PT AMAG & 3,19 \\
PT ASBI & 2,91 \\
PT ASJT & 3,70 \\
PT ASMI & 3,15 \\
PT ASRM & 2,15 \\
PT MREI & 4,55 \\
PT PNIN & 7,58 \\
PT PNLF & 7,19 \\
PT VINS & 7,94 \\
\hline
\end{tabular}

Sumber : Data yang diolah

Tabel 4. Hasil Perhitungan dan Analisis

Metode Altman Z-Score pada tahun 2018

\begin{tabular}{lc}
\multicolumn{1}{c}{$\begin{array}{c}\text { Nama } \\
\text { Perusahaan }\end{array}$} & Z-Score \\
\hline PT ABDA & 6,37 \\
PT AHAP & 3,91 \\
PT AMAG & 2,37 \\
PT ASBI & 2,49 \\
PT ASJT & 2,98 \\
PT ASMI & 3,34 \\
PT ASRM & 2,36 \\
PT MREI & 3,61 \\
PT PNIN & 7,28 \\
PT PNLF & 7,72 \\
PT VINS & 6,38
\end{tabular}

Sumber : Data yang diolah diatas, maka dapat dijelaskan tentang pengklasifikasian perusahaan asuransi yang berpotensi Sehat, Grey Area, dan Bangkrut. Berdasarkan nilai Z-Score tahun 2015 sampai dengan 2018 diatas terdapat 4 (empat) perusahaan dalam keadaan sehat atau tidak bangkrut yaitu 11 perusahaan asuransi yang diteliti oleh peneliti menunjukkan bahwa ada satu perusahaan yang dalam empat tahun berjalan mengalami sedikit masalah dalam manajemen maupun struktur keuangan namun masih dapat ditangani dengan cepat karena perusahaan masih dalam kondisi rawan, yaitu hasil perhitungan $\mathrm{Z}$ pada tahun 2015 sampai 2108 PT Asuransi Ramayana Tbk (ASRM) memiliki nilai cut off sebesar 1,96 , 2,09 2,15 , 2,36 Z 2,60 maka perusahaan dinyatakan sedikit mengalami masalah manajemen maupun struktur keuangan sehingga diprediksi perusahaan masih bisa ditangani karena perusahaan masih dalam kondisi rawan. selain PT Asuransi Ramayana mengalami kondisi rawan dalam empat tahun berjalan ada tiga perusahaan lainnya yang diprediksi dalam kondisi (zona) rawan yaitu PT Multi Artha Guna (AMAG) memiliki nilai cut off pada tahun 2018 sebesar $2,37 \mathrm{Z}<2,60$, PT Asuransi Bintang (ASBI) memiliki nilai cut off pada tahun 2018 sebesar $2,49 \mathrm{Z}<2$, 60 , Asuransi Mitra Maparya (ASMI), 
memiliki nilai cut off pada tahun 2015 sebesar 1,55 Z 2,60 maka ketiga perusahaan dinyatakan sedikit mengalami masalah manajemen maupun struktur keuangan sehingga diprediksi perusahaan masih bisa ditangani karena perusahaan masih dalam kondisi rawan (50:50).

\section{Pembahasan}

Perusahaan Asuransi yang berada di zona aman (tidak bangkrut) selama tahun 2015 sampai 2018 adalah tujuh perusahaan yaitu : PT. Asuransi Bina Dana Artha Tbk, PT Asuransi Harta Aman Pratama Tbk, PT Asurasi Jasa Tania Tbk, PT Maskapai Reasuransi Indonesia Tbk, PT Panin Insurance Tbk, PT Financial Tbk, PT Victoria Insurance Tbk. Dapat dilihat struktur keuangan pada perusahaan tersebut sangat baik sehingga selama empat tahun berjalan perusahan - perusahaan tersebut dinyatakan tidak bangkrut.

Dan Perusahaan Asuransi yang berada di zona rawan (grey area) selama tahun 2015 sampai tahun 2018 berdasarkan laporan keuangan pada tahun 2015 sampai pada tahun 2018 menyimpulkan bahwa ada empat perusahaan yaitu PT Asuransi Multi Artha Guna Tbk , PT Asuransi Bintang Tbk, PT Asuransi Ramayana Tbk dan PT Asuransi Mitra Maparya Tbk dinyatakan perusahaan yang mengalami kondisi rawan (grey area) yang artinya hampir dalam kondisi bangkrut dan hampir dalam kondisi aman tergantung pada keempat perusahaan dalam menangani struktur keuangan dan manajemen. Untuk perusahaan Asuransi yang dalam kondisi bangkrut pada tahun 2015 sampai 2018 tidak ada.

\section{Kesimpulan}

Perusahaan Asuransi yang berada di zona aman (tidak bangkrut) selama tahun 2015 sampai 2018 terdapat tujuh perusahaan. Ke tujuh perusahaan tersebut memiliki kas lebih tinggi dibandingkan dengan reliabilitas-nya, sehingga perusahaan- perusahaan tersebut berada di zona aman. Dapat dilihat struktur keuangan pada perusahaan tersebut sangat baik sehingga selama empat tahun berjalan perusahan - perusahaan tersebut dinyatakan tidak bangkrut.

Perusahaan Asuransi yang berada di zona rawan (grey area) selama tahun 2015 sampai tahun 2018 menyimpulkan bahwa ada empat perusahaan yaitu PT Asuransi Multi Artha Guna Tbk , PT Asuransi Bintang Tbk, PT Asuransi Ramayana Tbk dan PT Asuransi Mitra Maparya Tbk. Kesimpulan ini dapat di ambil karena berdasarkan laporan pembukuan, dimana liabilitas lebih tinggi dibandingkan current asset. Perusahaan yang mengalami kondisi rawan (grey area) artinya hampir dalam kondisi bangkrut dan hampir dalam kondisi 
aman tergantung pada keempat perusahaan dalam menangani struktur keuangan dan manajemen. Untuk perusahaan Asuransi yang dalam kondisi bangkrut pada tahun 2015 sampai 2018 tidak ada.

\section{Saran}

Berdasarkan hasil penelitian maka penulis dapat memberikan saran sebagai berikut :

Bagi manajemen perusahaan asuransi harus memperhatikan besarnya rasio, baik rasio modal kerja, rasio laba ditahan, rasio laba sebelum pajak serta rasio nilai ekuitas terhadap total utang. Hal tersebut karena besar - kecilnya nilai rasio akan memberi gambaran mengenai keberlangsungan usaha perusahaan di masa yang akan datang.

Data yang digunakan dalam penelitian ini merupakan data publikasi dan bisa jadi merupakan data yang telah diolah. Sehingga diharapkan bagi peneliti selanjutnya untuk dapat memperoleh data yang berasal dari sumber yang tepat.

Dalam menentukan kinerja perusahaan asuransi, diharapkan peneliti selanjutnya dapat melakukan analisis yang lebih komprehensif antara rasio keuangan Altman Z'Score dengan alat ukur yang telah ditetapkan oleh Otoritas Jasa Keuangan sebagai Lembaga yang bertanggung jawab terhadap lembaga lembaga keuangan di Indonesia.

\section{Daftar Pustaka}

Pangaribuan, Emmy (2015). Analisis Altman (Z-Score) "Sebagai Salah Satu Cara Untuk Mengukur Potensi Kebangkrutan Perusahaan", (Studi pada Perusahaan Manufaktur yang Listing di BEI dan Perusahaan Manufaktur yang Delisting dari BEI Periode 2012-2014), Skripsi Malang, FIB Universitas Brawijaya

Hanafi, Mamduh M. dan Abdul Halim. 2012. Analisis Laporan Keuangan. Yogyakarta: UPP AMP YKPN

Kasmir. (2014), "Bank dan Lembaga Keuangan Lainnya", Jakarta : Penerbit PT Raja Grafindo Persada

S, Munawir. 2012. "Analisis Informasi Keuangan". Yogyakarta: Liberty Yogyakarta, 2012

Toto. Prihadi. 2011. Analisis Laporan Keuangan Teori dan Aplikasi. Jakarta: PPM

Suad Husnan dab E. Pujiastuti (2015). Dasar-dasar Manajemen Keuangan, edisi keenam, UPP STIM TKPN, Yogyakarta. 